\title{
AUTOLOGOUS TISSUE CARDIAC VALVE: IMPLANTATION IN CHILDREN
}

\author{
Henry J. C. M. van de Wal, MD, PhD, Ger B. W. E. Bennink, MD, PhD, Marco C. Haanschoten, MD, and \\ Erik J. Meijboom, MD, PhD, Utrecht, The Netherlands
}

Renewed interest has arisen in the use of autologous tissue for both the reconstruction and construction of heart valves, to avoid the problems of calcification and primary tissue failure found with heterograft bioprostheses and homograft valves. A method of intraoperative fabrication of an autologous tissue cardiac valve (ATCV) was described by Love and colleagues. ${ }^{1}$ The kit used to construct the valve makes the assembly of the ATCV simple and straightforward. As recommended by the National Institutes of Health, in vivo testing showed excellent hemodynamic properties and no evidence of generalized calcification in the juvenile sheep model. In the clinical series, early follow-up results have also indicated good hemodynamic performance of the ATCV without regurgitation. On the basis of these encouraging results, the ATCV was used in a 4-year-old girl. This report describes the theoretic justification and advantages of using this valve in children.

A 4-year-old girl, $16.2 \mathrm{~kg}$ in weight and $105 \mathrm{~cm}$ in height, was found to have coarctation of the aorta and aortic valve stenosis. When 3 years old, she underwent a balloon dilatation of both lesions, which resulted in diminished gradients across both the aortic valve and the coarctation (32 to $7 \mathrm{~mm} \mathrm{Hg}$ and 15 to $7 \mathrm{~mm} \mathrm{Hg}$, respectively); however, an aortic insufficiency of $3 / 4$ appeared. Because of increasing aortic insufficiency, residual stenosis, mitral insufficiency, and left ventricular hypertrophy, the patient was then accepted for mitral valve plasty and aortic valve replacement. A mechanical valve would ordinarily have been preferred; after informed consent was obtained, however, an autologous valve was selected because of the absence of calcification in the sheep experiment.

During operation, the native valve was found to be thickened and fibrosed, with the right cusp absent. After the leaflets were removed, a $14 \mathrm{~mm}$ Hegar dilatator could be introduced through the anulus. Once root enlargement was completed with Manougian and Seybold-Epting's technique, ${ }^{2}$ the annular size was increased to allow implantation of a $19 \mathrm{~mm}$ Autogenics valve (Autogenics, Newbury Park, Calif.). Inspection of the mitral valve showed a prolapsed posterior leaflet, which was corrected by quandrangular resection. After declamping, sinus rhythm recurred and the patient was easily weaned from extracorporeal circulation.

From the Paediatric Heart Centre, Wilhelmina Children's Hospital, Utrecht, The Netherlands.

Received for publication August 15, 1995; accepted for publication Jan. 24, 1996.

J Thorac Cardiovasc Surg 1996;112:846-8

Copyright $\mathbb{C} 1996$ by Mosby-Year Book, Inc.

$0022-5223 / 96 \$ 5.00+0 \quad \mathbf{1 2 / 5 4 / 7 2 3 2 0}$
The postoperative course was complicated by an airway infection that was treated successfully with antibiotics. Echocardiography revealed neither insufficiency nor residual stenosis across the aortic or mitral valve (Doppler gradient of zero). On postoperative day 20 , the patient was discharged. Follow-up after 2 months did not show any cardiac complaints, and echocardiographic results were unchanged.

The intraoperative fabrication method of the ATCV, as described by Love and colleagues, ${ }^{1}$ is shown in Fig. 1 . The ATCV is constructed of autologous pericardium that has been cleaned of fatty tissue. The autologous pericardium is treated by brief immersion in a buffered $0.6 \%$ glutaraldehyde solution. Once the patient's anulus has been sized, the valve is constructed while the sutures are placed in the anulus.

Before implantation, the ATCV is tested. With the provided Acceptance Test Device (Autogenics), the ATCV can be functionally examined. ${ }^{4}$ This device allows the cycling of sterile saline solution through the valve with a closing pressure of $85 \mathrm{~mm} \mathrm{Hg}$; it also enables the surgeon to examine both the profile and the outflow end of the valve for prolapse, pinwheeling, and good coaptation.

Making a heart valve prosthesis from the patient's own tissue is more appealing than using animal tissue. This is not a new idea; Senning began implanting autologous fascia lata valves in 1962. Senning's work inspired subsequent trials with fascia lata valves by Ionescu ${ }^{6}$ and $\mathrm{Ed}-$ wards ${ }^{7}$ and with pericardium by Björk and Hultquist. ${ }^{8}$ These early experimental uses of autologous tissue were not successful because of problems with both the tissue and the methods used for construction. The fresh, untreated tissue was subject to thickening and shrinkage, which led to early valve failure. When pericardium was treated with a 5-minute immersion in $0.6 \%$ glutaraldehyde, the autologous tissue valves did not show thickening, shrinkage, or generalized calcific degeneration after 5 months in the juvenile sheep model. General tissue changes in bioprosthetic valves regularly occur after a couple of months in this model, whereas such changes take years to develop in human beings. Carpentier and associates ${ }^{9}$ reported the absence of macroscopic calcification of the pericardium patches briefly immersed in glutaraldehyde used for mitral valve reconstruction in young patients as long as 10 years after operation. More recently, Chauvaud and colleagues ${ }^{10}$ reported similar use of autologous pericardium as annular reinforcement in cases of mitral valvuloplasty after 10 -minute immersion in glutaraldehyde. Their group has seen no calcification of this tissue in patients as late as 10 years of follow-up. The ATCV is made simple and straightforward by the use of a kit. The stent assembly has been cycled more than 800 million times in the wear tester without failure. Laboratory tests in animals indicate that the autologous valve 

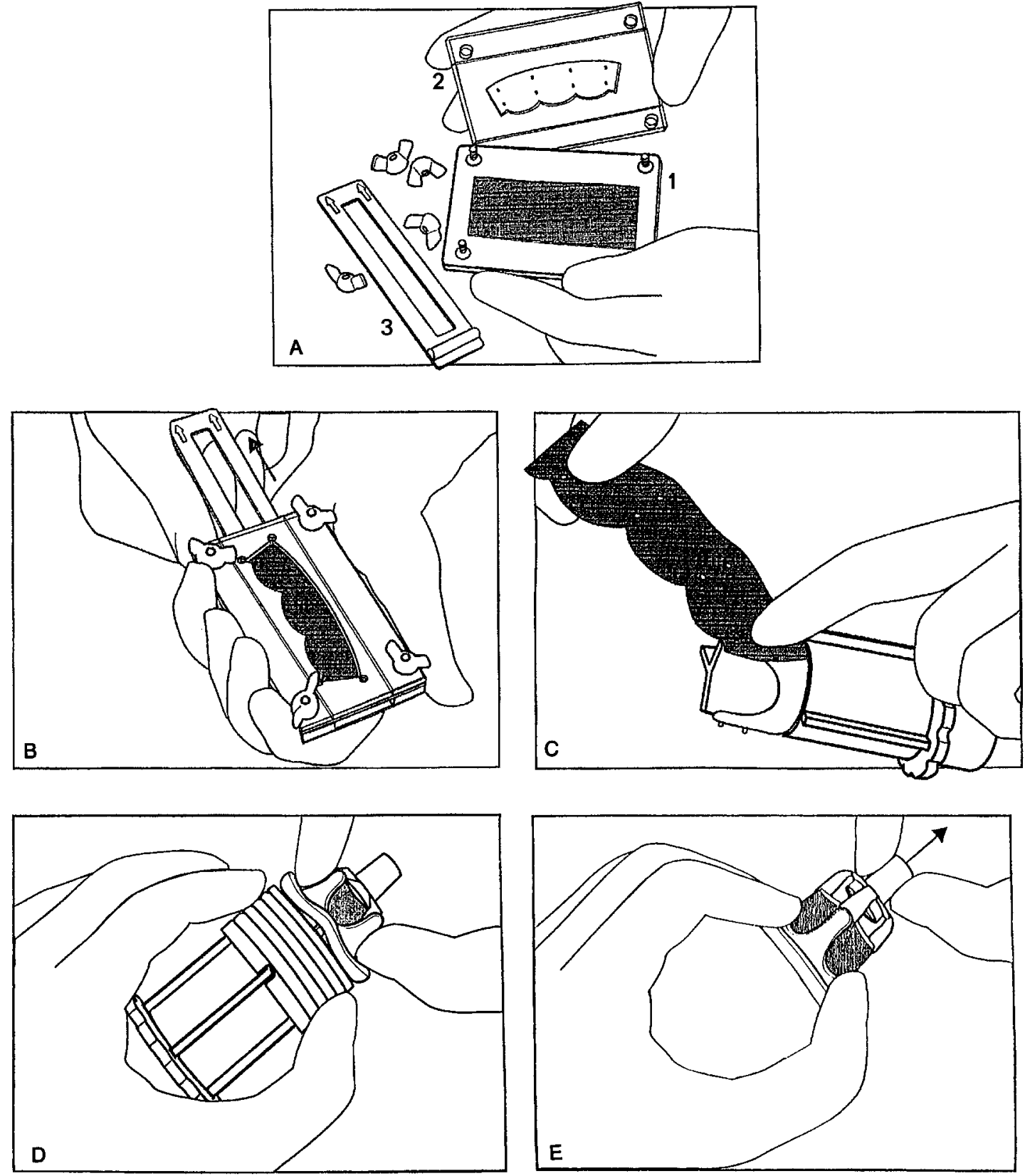

Fig. 1. A, Laying tissue on tissue-cutting die. 1, Tissue-cutting die; 2, preformed cutting blade; 3 , pusher device. B, Assembled cutting device cutting tissue by pulling through pusher device. $\mathbf{C}$, Wrapping tissue on inner stent, applying precut holes to buttons on stent. D, Lowering outer stent over inner stent, protecting buttons with cap. E, Removing protective cap from finished valve.

may be more durable and resistant to calcification and degeneration than animal tissue valves, even in children. There is published evidence that the durability of heterograft valves may be a function of the residual immunogenicity of those valves after glutaraldehyde tanning of the tissue. $^{11}$
A clinical trial in which 360 patients have been enrolled has been underway since 1992. There have been 21 deaths, none of which were attributed to failure of the Autogenics valve. On the basis of these encouraging results, we consider implantation of this valve in children to be justified. 
We thank the operating team, Miek Remmers, perfusionist, José Voncken, scrub nurse, and Daniëlle Westermann, nurse anesthetist, for their cooperation during the operation.

\section{REFERENCES}

1. Love JW, Calvin JH, Phelan RF, Love CS. Rapid intraoperative fabrication of an autologous tissue heart valve: a new technique. In: Bodnar E, Yacoub M, editors. Proceeding of the Third International Symposium on Cardiac Bioprothesis, Avignon, France. New York: Yorke Medical Books, 1986: 691-8.

2. Fabiani JN, Dreyfus GD, Marchand M, Jourdan J, Anpard $\mathrm{M}$, Latrémonille C, et al. The autologous tissue cardiac valve: a new paradigm for heart valve replacement. Ann Thorac Surg 1995;60:S189-94.

3. Manouguian S, Seybold-Epting W. Patch enlargement of the aortic valve ring by extending the aortic incision into the anterior mitral leaflet. J Thorac Cardiovasc Surg 1979;78: 402-12.

4. Hudspeth AS, Cordel AR. A method for testing aortic valvular function during open repair. $\mathbf{J}$ Thorac Cardiovasc Surg 1963;45:813-6.

5. Senning A. Fascia lata replacement of aortic valves. J Thorac Cardiovasc Surg 1967;54:465-70.

6. Ionescu MI, Ross DN. Heart valve replacement with autologous fascia lata. Lancet 1969;2:335-8.

7. Edwards WS, Holdefer WF. Partial and complete reconstruc tion of the mitral valve with pericardium. In: Brewer L, editor. Prosthetic heart valves. Springfield (IL): Charles C Thomas, 1969:820-31.

8. Björk VO, Hultquist G. Tefion and pericardial aortic valve prostheses. J Thorac Cardiovasc Surg 1964;47:693-701.

9. Carpentier A, Lamaigre CG, Robert L, Carpentier S, Dubost C. Biological factors affecting long term results of valvular heterografts. J Thorac Cardiovasc Surg 1969;58:467-83.

10. Chauvaud S, Jebara V, Chachques JC, Asmar BE, Mihaileanu S, Perier $P$, et al. Valve extension with glutaraldehyde-preserved autologous pericardium. J Thorac Cardiovasc Surg 1991;102:171-8.

11. Love CS, Love JW. The autologous tissue heart valve: current status. J Cardiac Surg 1991;6:499-507. 